НАУКОВИЙ ВІСНИК

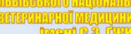

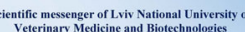

1

$\sqrt{3}$

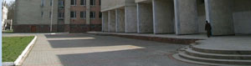

СЕРЯя: ВЕТЕРИНАРНН НАУКИ

Toм 23 № 101

2021
Науковий вісник Дьвівського національного університету ветеринарної медицини та біотехнологій імені С.3. Гжицького. Серія: Ветеринарні науки

\author{
Scientific Messenger of Lviv National University \\ of Veterinary Medicine and Biotechnologies. \\ Series: Veterinary sciences
}

UDC 619:636.8:591.437:616.37-002.4

\title{
Specific features of morphological structure of cat pancreas under pancreatitis
}

\author{
L. P. Goralskyi, O. M. Kovalchuk, I. M. Sokulskyi, N. L. Kolesnik \\ Polissia National University, Zhytomyr, Ukraine
}

Article info

Received 30.12.2020

Received in revised form 01.02 .2021

Accepted 02.02.2021

Polissia national university, Staryj Boulevard, 7, Zhytomyr, 10002, Ukraine.

Tel.: +38-097-785-73-20

E-mail: sokulskiy_1979@ukr.net
Goralskyi L. P., Kovalchuk O. M., Sokulskyi I. M., \& Kolesnik N. L. (2021). Specific features of morphological structure of cat pancreas under pancreatitis. Scientific Messenger of Lviv National University of Veterinary Medicine and Biotechnologies. Series: Veterinary sciences, 23(101), 38 43. doi: $10.32718 /$ nvlvet10107

A scientific paper is devoted to studying histomorphology of healthy cats' pancreas under acute pancreatitis. A pancreas was taken for a histological analysis ( $n=6$ in each group) from healthy cats, who died because of fatal injuries. The material under acute pancreatitis was taken in a scientific work-training clinic from the cats who died because of the pathalogical processes of a given pathology, or sick animals were put to death because of their critical condition and upon the consent of animal's owner. Histological analysis of pancreas tissue were carried out in the laboratory of pathomorphology which is under the jurisdiction of the Department of Anatomy and Histology of Polissia National University. Histologic sections (from 8 to 12 micron thick) of a pancreas of both groups were painted with Ehrlich's, Carazzi's hematoxylin and with eozyn applying a method of Van-Gizon, after which light microscopy and microphotography of tissue specimens were carried out. Animal pancreas is of parenchymal structure, it is divided into particles consisting of pancreatic acinuses which have sharp contours of inter-acinus, internal and inter-particle canals as well as of the main canals. There are Langerhans islets (endocrine cells accumulation) among acinuses. When studying a histological structure of a gland under acute pancreatitis, some widening of inter-acinus space of a gland, a well-defined interstitial swelling and hyperemia of stroma were observed. Acinal cells (pancreatocytes of exocrine pancreas) were in a state of granular degeneration, another part of such cells was in a state of hydropic degeneration. The acinus size increased. Some acinuses lost their typical form and did not have a well-defined structure. In a gland histostructure the amount of fibroblasts, fibrocytes and synthesized collagen fibers, which were painted bright-red applying Van-Gizon method, increased. A histological structure of endocrine pancreas, which is repesented by islets of Langerhans, had some hemorrhages and burned-out cells. The islets contours were not well-defined, their capsules were ruptured on all areas. There was total necrosis of endocrine cells, islets capillaries were widened anf filled with blood. Some local hemorrhages and chromatin margination in some nuclei of different types of cells were revealed. According to organometry indices of a gland, the absolute weight of a gland $(P \leq 0,05)$ increased by 1.24 time as compared with a clinically healthy animals, that accounted for становило $6.82 \pm 2.31 \mathrm{~g}$, and in clinically healthy cats $-5.5 \pm 1.82 \mathrm{~g}$. Relative gland mass increased by 1.3 times and equalled $0.50 \pm 0.03 \%$.

Key words: morphology, pancreatic acinus, inter-acinus space, istels of Langerhans, interstitial swelling, necrosis, local hemorrhages, chromatin margination.

\section{Особливості морфологічної будови підшлункової залози котів за панкреатиту}

\author{
Л. П. Горальський, О. М. Ковальчук, І. М. Сокульський, Н. Л. Колеснік
}

Поліський наџіональний університет, м. Житомир, Украӥна

\footnotetext{
Стаття присвячена дослідженню гістоморфологї підилункової залози клінічно здорових котів за гострого панкреатиту. Для гістологічного дослідження відбирали підшлункову залозу (n =6, у кожній групі), від клінічно-здорових котів, які загинули внаслідок отриманих травм, несумісних із життям. Матеріал за гострого панкреатиту відібрали у котів, які загинули внаслідок розвитку патологічних прочесів даної патологіі, або проводили евтаназію хворих тварин у зв'язку з тяжким їхнім станом і за згодою власників тварин у навчально-науково-виробничій клініці ветеринарної медицини. Гістологічні дослідження тканини підилункової
} 
залози проводили у лабораторії патоморфологіi при кафедрі анатомії і гістології Поліського національного університету. Гістологічні зрізи завтовшки від 8 до 12 мкм підилункової залози обох груп фарбували гематоксиліном Ерліха, Караці та еозином і за методом Ван-Гізона, після чого проводили світлову мікроскопію та мікрофотографування гістопрепаратів. Підилункова залоза тварин паренхіматозної будови, розділена на часточки, останні складаються із панкреатичних ацинусів, які мають чіткі контури, і міжацинусних, внутріщньо та міжчасточкових і головних проток. Між ацинусами розміщенні острівці Лангерганса (скупчення ендокринних клітин). При дослідженні гістологічної будови залози за гострого панкреатиту спостерігали розширення міжацинарного простору залози, був виражений інтерстеціальний набряк та повнокрів'я строми. Ацинарні клітини - панкреатоциттів екзокринної частини, були у стані зернистої дистрофії, інша частина таких клітин мала гідропічну дистрофію. Розміри ацинусів збільшувались. Окремі ацинуси втрачали властиву їм форму та не мали чіткої структури. У гістоструктурі залози помітно збільшувалась кількість фібробластів, фіброцитів та синтезованих ними колагенових волокон, котрі за методом ВанГізона інтенсивно зафарбовувались у яскраво-червоний колір. Гістологічна будова ендокринної частини підилункової залози, яка представлена острівиями Лангерганса, відзначалась крововиливами та дистрофічно зміненими клітинами, контури острівців були нечіткими, їхні капсули розірвані по всіх ділянках. У частині острівців Лангерганса виявляли тотальний некроз їх ендокриноцитів, капіляри острівців були розширеними та інтенсивно наповнені кров 'ю. Виявляли вогнищеві крововиливи та маргінацію хроматину в частині ядер клітин різних типів. За органометричними показниками залози було встановлено достовірне збільшення абсолютної маса залози $(P \leq 0,05)$ у 1,24 раза порівняно з клінічно здоровими тваринами, ш⿻о становило 6,82 $\pm 2,31$ 2, а у клінічно-здорових

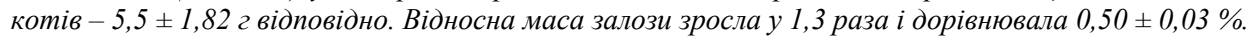

Ключові слова: морфологія, панкреатичні ацинуси, міжацинарний простір, острівці Лангерганса, інтерстеціальний набряк, некроз, вогнищеві крововиливи, маргінація хроматину.

\section{Вступ}

Підшлункова залоза, у якій поєднана зовнішньосекреторна та ендокринна функції, бере активну участь майже у всіх фізіологічних процесах в організмі (Hushchyn et al., 2018), починаючи від травлення і до процесів адаптації, в тому числі - у підтриманні гомеостазу всього організму (Horalskyi et al., 2016; Didenko, 2017). Вона синтезує ферменти (трипсин, ліпазу, амілазу тощо), які необхідні для перетравлення білків, жирів та вуглеводів (Horalskyi et al., 2021). В ендокринній частині залози виробляються гормони (інсулін, глюкагон, соматостатин тощо), які регулюють вміст цукру в крові та підтримують певний рівень гомеостазу в організмі (Horalskyi et al., 2019).

Актуальність теми. Останнім часом в Україні та за іiі межами, згідно зі статистичними даними, у людей та тварин помітно зростають патології щодо порушення зовнішньосекреторної функції підшлункової залози - це гострий та хронічний панкреатит (Berehovenko \& Zinenko, 2008; Dybuch, 2008; Zinenko \& Tverdokhlib, 2017; Kotsyumbas et al., 2018; Kovalchuk \& Horalska, 2018; Milastnaia \& Dukhnitsky, 2019). Порушення екзокринної функції підшлункової залози внаслідок запального процесу може бути причиною ендогенної інтоксикації організму з багатокомпонентним системним запальним синдромом, що часто призводить до летальних випадків внаслідок розвитку поліорганної недостатності (Zinenko, \& Tverdokhlib, 2020). Не викликає сумніву, що панкреатит у домашніх тварин, в тому числі котів, залишається однією 3 найбільш поширених хвороб і недостатньо з'ясованих причин захворюваності та смертності тварин цього виду (Tymoshenko, 2007; Kravchenko \& Bobrova, 2018). Так, за даними літературних джерел, смертність у котів за ускладненого перебігу гострого панкреатиту коливається в межах від 27 \% до 42 \% (Tuboltseva \& Zhukov, 2018). Водночас морфологічне виявлення змін у функціональних клітинах та тканинах підшлункової залози за панкреатиту дозволяє більш детально розкрити пато- і морфогенез (залежно від функціональних порушень), оптимізувати патогенетичну терапію, своєчасно призначити профілактику патології підшлункової залози (Filonenko \& Klimov, 2009). При дослідженні котів патоморфологічні зміни, характерні для хронічного панкреатиту, виявляли у 60 \% тварин, а морфологічні ознаки за гострого панкреатиту - у 30 \% (Tuboltseva \& Zhukov, 2018).

Проте дані морфологічних досліджень щодо патології підшлункової залози у тварин за гострого панкреатиту неоднозначні. Тому, враховуючи важливість підшлункової залози не тільки як органа травної системи, а й такого, що характеризує загальний стан усього організму, актуальним є дослідження іiі структурної організації у клінічно здорових тварин та за панкреатиту, що обумовило мету роботи.

Мета роботи - дослідити гістоморфологію підшлункової залози у клінічно здорових котів та за гострого панкреатиту.

\section{Матеріал і методи досліджень}

Робота виконувалась на кафедрі анатомії і гістології упродовж 2017-2021 років на базі навчальнонауково-виробничої клініки та в умовах клінікодіагностичної лабораторії факультету ветеринарної медицини Поліського національного університету. Матеріалом для дослідження були безпородні клінічно здорові та хворі на панкреатит коти, що утримувалися в приватному секторі (м. Житомир).

Відбір матеріалу для морфологічних досліджень підшлункової залози проводили від клінічно здорових та загиблих котів (n =6, у кожній групі), внаслідок отриманих травм, несумісних з життям, і які не мали патологій шлунково-кишкового тракту.

Відбір матеріалу у котів за гострого панкреатиту проводили у хворих тварин, які підлягали евтаназії у зв'язку з тяжким їх станом і за згодою власників тварин, або від загиблих котів внаслідок розвитку патологічних процесів за гострого панкреатиту. При цьому дотримувались правил належної лабораторної практики GLP (1981), положень “Загальних етичних принципів експериментів на тваринах”, ухвалених I Національним конгресом 3 біоетики (м. Київ, 2001 р.) та вимог до "Правил проведення робіт з використанням експериментальних тварин”, затвердже- 
них наказом Міністерства охорони здоров’я № 281 від 1 листопада 2000 р. "Про заходи щодо подальшого удосконалення організаційних форм роботи з використанням експериментальних тварин" (Yablonska, 2007).

Перед відбором тварин для досліджень було проведено диспансерне клінічне обстеження котів, яке включало: огляд, пульсо- та термометрію, аускультацію, перкусію, з обов'язковим лабораторним дослідженням їх крові, що включало визначення кількості еритроцитів, лейкоцитів, рівня гемоглобіну, вмісту загального білка в сироватці крові, альбумінів, загального білірубіну, активності ферментів АЛТ, АСТ, ГГТП, лужної фосфатази, $\alpha$-амілази, креатиніну та сечовини (Levchenko et al., 2002; Kondrakhyn et al., 2004; Meier \& Kharvy, 2007) за допомогою напівавтоматичного аналізатора.

Для морфологічних досліджень та проведення морфометричного аналізу відбирали підшлункову залозу від клінічно здорових та хворих на гострий панкреатит котів, визначали абсолютну i відносну масу, довжину та ширину часток органа.

Шматочки матеріалу, об'ємом $1 \mathrm{~cm}^{3}$, фіксували в 10-12\% розчині нейтрального формаліну з подальшою заливкою у парафін (Horalskyi et al., 2019). Після фіксації та промивки шматочків підшлункової залози проводили їх через спирти зростаючої міцності і ксилол та заливали у парафін. Потім з парафінових блоків виготовляли гістологічні зрізи на санному мікротомі МС - 2 завтовшки від 8 до 12 мкм (Horalskyi et al., 2019).

Для дослідження морфології клітин і тканин підшлункової залози, застосовували фарбування гістозрізів гематоксиліном Ерліха, Караці та еозином і за методом Ван-Гізона (Horalskyi et al., 2019).

Мікрофотографування гістологічних препаратів здійснювали за допомогою відеокамери САM V200, вмонтованої в мікроскоп Micros MC-50.

\section{Результати та їх обговорення}

Виявлення хворих на панкреатит тварин починали iз детального збору анамнестичних даних. Для постановки діагнозу прижиттєвими клінічними методами дослідити підшлункову залозу у хворих котів досить важко через складну ії морфологічну будову і топографію. Тому про стан підшлункової залози ми судили за типовими симптомами для гострого панкреатиту. При проведенні патологоанатомічного розтину тварин ретельно вивчали розміри, колір орана, консистенцію та стан паренхіми у нормі та за патології. Заключний діагноз - панкреатит котів - ми ставили на підставі клінічного огляду хворих тварин, виявлення характерних симптомів для гострого панкреатиту - інтенсивний біль у краніальній ділянці живота, блювання тощо та проведення лабораторних досліджень морфологічного і біохімічного складу крові, у результаті чого з'ясовано особливості перебігу та деякі діагностичні аспекти панкреатиту у котів.

Згідно з результатами клінічних спостережень за гострого перебігу панкреатиту видимі слизові оболонки та кон'юнктива були анемічними, спостерігали загальну слабкість, пронос, періодичне блювання, прогресуюче зневоднення, олігурію. При пальпації стінка черевної порожнини була напружена, болюча. У таких тварин спостерігали обмеженість рухових функцій. Виявляли гастроентерити, в окремих котів спостерігали метеоризм кишечника, порушення перистальтики. Подібні зміни у хворих котів за гострого панкреатиту виявляли (Ksenulis \& Shtainer, 2009).

Стосовно наших досліджень, найчастіше на гострий панкреатит хворіють коти молодого віку, особливо тварини на етапі переходу їх 3 молочного типу годівлі на інший тип годівлі.

У хворих котів, на відміну від здорових, підшлункова залоза за гострого перебігу панкреатиту збільшена, темно-червоного кольору, набрякла (рис. 1). Згідно з результатами досліджень (Kuksenko, 2002) було виявлено подібні макроскопічні зміни при гострому панкреатиті собак.

\section{Таблиця 1}

Органометричні показники підшлункової залози котів, клінічно здорових та хворих на гострий панкреатит (M \pm m)

\begin{tabular}{lcc}
\hline \multicolumn{1}{c}{ Показники } & \multicolumn{2}{c}{ Тварини } \\
\cline { 2 - 3 } & клінічно здорові, $\mathrm{n}=6$ & $6,82 \pm 2,31^{*}$ \\
\hline Абсолютна маса підшлункової залози, г & $5,5 \pm 1,82$ & $0,50 \pm 0,03 *$ \\
Відносна маса підшлункової залози, $\%$ & $0,39 \pm 0,06$ & $16,7 \pm 1,03 *$ \\
Довжина підшлункової залози, см & $14,18 \pm 0,96$ & $1,7 \pm 0,83$ \\
Ширина лівої частки, см & $1,28 \pm 0,72$ & $1,44 \pm 0,62$ \\
Ширина середньої частки, см & $1,04 \pm 0,28$ & $1,05 \pm 0,48$ \\
Ширина правої частки, см & $0,89 \pm 0,17$ & \\
\hline
\end{tabular}

Примітка: *P $\leq 0,05 ; * * P \leq 0,01 ; * * * P \leq 0,001$ щุодо клінічно здорових тварин.

Органометричними показниками встановлено, що абсолютна маса залози, порівняно з клінічно здоровими тваринами, достовірно $(\mathrm{P} \leq 0,05)$ збільшилась у 1,24 раза та становила $6,82 \pm 2,31$ г, у клінічно здорових котів $-5,5 \pm 1,82$ г. Відносна маса зросла у 1,3 раза і дорівнювала $0,50 \pm 0,03 \%$. Довжина П3 достовірно ( $\mathrm{P} \leq 0,05)$ збільшилась у 1,26 раза та скла- дала $16,7 \pm 1,03 \mathrm{~cm}$, водночас відбувалося достовірне (P $\leq 0,05)$ збільшення ширини лівої, середньої та правої часток у 1,$33 ; 1,39$ та 1,18 раза відповідно (табл. 1).

Гістологічна будова підшлункової залози у котів за гострого перебігу панкреатиту, порівняно 3 клінічно здоровими тваринами, змінювалась. Так, у окремих 
хворих котів виявляли розширення міжацинарного простору залози унаслідок його набряку, що свідчило про розвиток запальних процесів органа.

Ацинарні клітини - панкреатоцити - були у стані зернистої дистрофії, а у частини таких клітин окремих ацинусів спостерігали їх гідропічну дистрофію. Часто такі дистрофічні змінами супроводжувались лізисом ядер панкреатоцитів та некрозом екзокринної паренхіми (рис. 2) (Zinenko \& Beregovenko, 2008). Розміри ацинусів підшлункової залози котів за гострого панкреатиту збільшувались.

При дослідженні ендокринної частини у самих острівцях Лангерганса підшлункової залози виявляли вогнищеві крововиливи та маргінацію хроматину в частині ядер клітин різних типів - А-, Б-, Д, Д-1, РР та їх руйнування.

У деяких часточках підшлункової залози спостерігали дезінтеграцію окремих ацинусів. Такі ацинуси були сформовані хаотично розміщеними клітинами панкреатоцитами, які втратили полярну диференціацію, а їх ядра нечітко сприймали забарвлення, тому набували світлого вигляду і нечітко диференціювались у цитоплазмі клітин. Крім того, такі змінені ацинуси підшлункової залози часто формували комплекси у вигляді окремих груп.

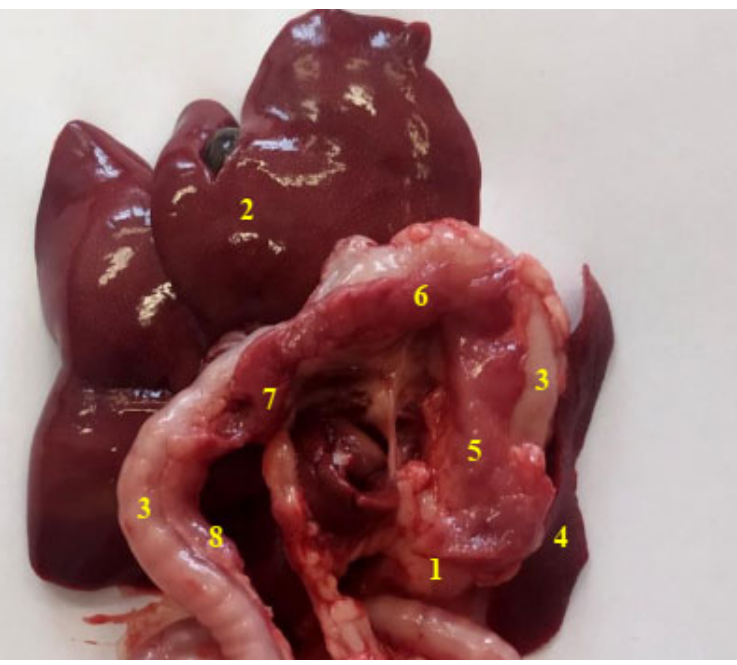

Рис. 1. Загальна будова підшлункової залози кота за гострого перебігу панкреатиту: 1 - пілорична частина шлунка; 2 - печінка; 3 - дванадцятипала кишка; 4 - селезінка; 5 - ліва частка залози; 6 - тіло залози; 7 - права частка залози; 8 - гачкоподібний згин. Макропрепарат

У частини хворих тварин екзокринна частина паренхіми підшлункової залози набувала некробіотичних змін, був виражений інтерстеціальний набряк та повнокров'я строми (що збігається 3 даними інших дослідників, які займались дослідженням патоморфології залози при перебігу гострого панкреатиту в експерименті (Morar et al., 2012). В поодиноких випадках спостерігали виражену геморагічну імбібіцію внутрішньочасточкової строми паренхіми. У iï гістоструктурі помітно збільшувалась кількість фібробластів, фіброцитів та синтезованих ними колагенових волокон, котрі за методом Ван-Гізона інтенсивно зафарбовувались у яскраво-червоний колір. Такі виявлені нами зміни свідчили про розростання волокнистої сполучної тканини в стромі підшлункової залози котів за гострого панкреатиту.

Крім того, досить часто виявлялись поодинокі вогнищеві крововиливи в екзокринній частині органа. Водночас судини мікроциркуляторного русла були

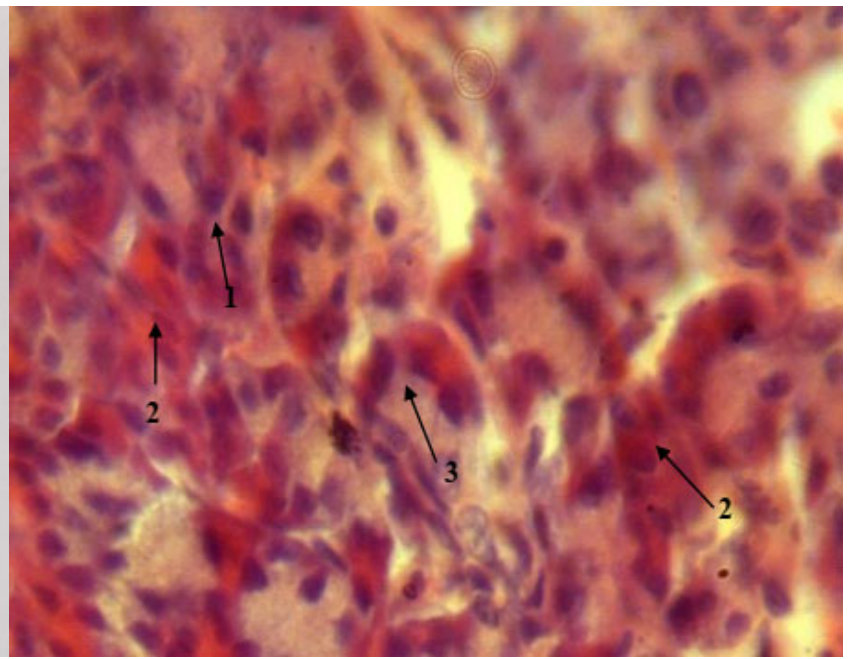

Рис. 2. Фрагмент гістологічної будови підшлункової залози кота за гострого перебігу панкреатиту:

1 - каріопікноз ядер; 2 - повнокров'я міжацинарного простору; 3 - некроз екзокринної паренхіми.

Гематоксилін Караці та еозин. $\times 400$

розширеними та наповнені кров'ю, а просвіт вивідних проток підшлункової залози розширений, їхні стінки перебували у стані набряку (рис. 3). До того ж, у деяких хворих тварин виявляли некротичні зміни екзокринної паренхіми залози, при цьому міжацинарний простір був заповнений кров'ю. Окремі ацинуси органа втрачали властиву їм форму та не мали чіткої гістоструктури. Їх панкреатоцити, які були на базальній мембрані, мали ядра у стані пікнозу. У капілярах, артеріолах та часто у венулах спостерігали різке повнокрів'я, набряк ендотеліоцитів та виявляли пристінкові тромби.

При дослідженні острівців Лангерганса ендокринної частини залози спостерігали крововиливи та дистрофічно змінені клітини, контури острівців були нечіткими, їхні капсули були розірванні по всіх ділянках, відмічено зменшення острівців. У частині острівців Лангерганса виявляли тотальний некроз їх ендокриноцитів (рис. 4). 


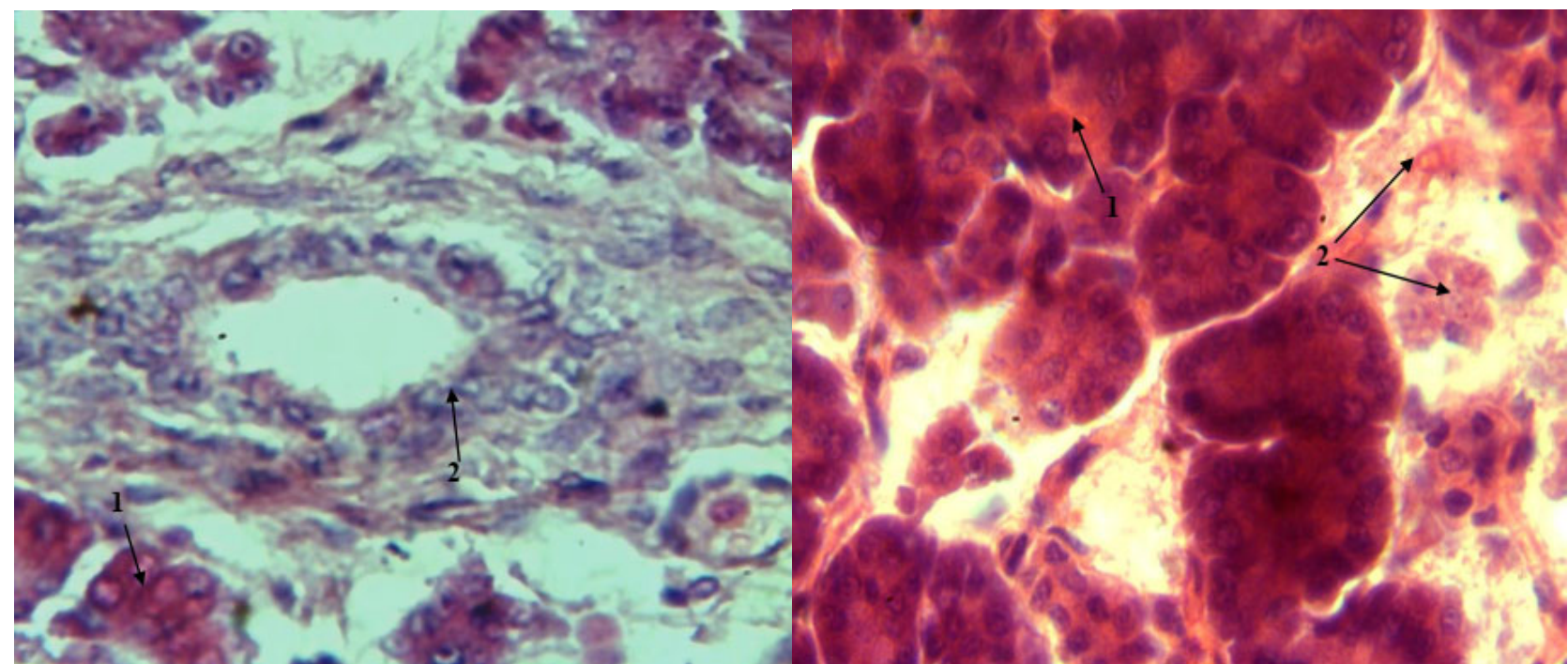

Рис. 3. Фрагмент гістологічної будови підшлункової залози кота за гострого перебігу панкреатиту: 1 - дискомплексація ацинусів; 2 - розширення та набряк стінки протоки екзокринної частини підшлункової залози. Гематоксилін Караці та еозин. ×400

\section{Висновки}

1. Перебіг патологічного процесу за гострого панкреатиту котів характеризується макроскопічними та органометричними змінами підшлункової залози: абсолютна маса підшлункової залози, порівняно 3 клінічно здоровими тваринами достовірно $(\mathrm{P} \leq 0,05)$ збільшується у 1,24 раза, відносна маса - у 1,3 раза. Довжина ПЗ достовірно $(\mathrm{P} \leq 0,05)$ зростає у 1,26 раза $(16,7 \pm 1,03$ см), ширина лівої частки - у 1,33, середньої - у 1,39, правої - у 1,18 раза.

2. Мікроскопічно гострий перебіг панкреатиту проявляється іiї змінами архітектоніки, які характеризуються розширенням міжацинарного простору внаслідок його набряку, некробіотичними змінами, поодинокими вогнищевими крововиливами у екзокринній частині органа, дезінтеграцією окремих ацинусів, зернистою та гідропічною дистрофією панкреатоцитів, зростанням кількість фібробластів, фіброцитів та синтезованих ними колагенових волокон, які за методом Ван-Гізона інтенсивно зафарбовувались у яскраво-червоний колір.

Перспективи подальших досліджень передбачають проведення гістохімічних досліджень паренхіми підшлункової залози котів у нормі та за гострого панкреатиту.

Відомості про конфлікт інтересів. Автори стверджують про відсутність конфлікту інтересів щодо їх вкладу та результатів досліджень.

\section{References}

Berehovenko, I. M., \& Zinenko D. Yu. (2008). Mikrotsyrkuliatorni y patomorfolohichni zminy $u$
Рис. 4. Фрагмент гістологічної будови ендокринної частини підшлункової залози кота за гострого перебігу панкреатиту: 1 - вогнищеві крововиливи в ендокринній паренхімі залози; 2 - некроз клітин острівця Лангерганса. Гематоксилін Караці та еозин. ×400

rozvytku eksperymentalnoho hostroho pankreatytu u shchuriv. Morfolohiia, 1, 33-38 (in Ukrainian).

Didenko, I. S. (2017). Zminy histolohichnoi struktury pidshlunkovoi zalozy za umov aloksanovoi hiperhlikemii u shchuriv u vikovomu aspekti. Ukrainskyi zhurnal medytsyny, biolohii ta sportu, 6(8), 17-20. doi: 10.26693/jmbs02.06.017 (in Ukrainian).

Dubych, I. M. (2008). Histomorfolohiia ta orhanometrychni pokaznyky pidshlunkovoi zalozy tsutseniat [Histomorphology and organometric parameters of the pancreas of puppies]. Nauk. visnyk Lvivskoho natsionalnoho universytetu veterynarnoi medytsyny ta biotekhnolohii im. S. Z. Hzhytskoho, 3(38), 73-76 (in Ukrainian).

Filonenko, T. H., \& Klimov, A. O. (2009). Histolohichni zminy $\mathrm{v}$ pidshlunkovii zalozi $\mathrm{v}$ razi hostroho $\mathrm{y}$ khronichnoho pankreatytu $\mathrm{V}$ sobak [Histological changes in the pancreas in acute and chronic pancreatitis in dogs] Veterynarna medytsyna Ukrainy, 12, $27-$ 28 (in Ukrainian).

Horalskyi, L. P., Khomych, V. T., \& Kononskyi, O. I. (2019). Osnovy histolohichnoi tekhniky i morfofunktsionalni metody doslidzhennia u normi ta pry patolohii [Fundamentals of histological technique and morphofunctional research methods in normal and pathological conditions] Polissia, Zhytomyr, 288 (in Ukrainian).

Horalskyi, L. P., Kovalchuk, O. M., Gutyj, B. V., Sokulskyi I. M. (2021). Pathomorphological features of the pancreas in mature cats with acute pancreatitis. Colloquium-Journal. Veterinary Science, 7(94), 8-9. doi: 10.24412/2520-6990-2021-794-7-12.

Horalskyi, L. P., Sokulskyi, I. M., \& Demus, N.V. (2016). Pidshlunkovoi zalozy sobak za khronichnoho pankreatytu. Naukovyi visnyk LNUVMBT imeni S. Z. 
Gzhytskoho, 3(70), 40-43. doi:10.15421/nvlvet7010 (in Ukrainian).

Hushchyn, Ya. Y., Shedko, V. V., Muzhykian, A. A., Makarova, M. N., \& Makarov, V. H. (2018). Sravnitelnaia morfolohiya podzheludochnoy zhelezy eksperimentalnykh zhyvotnykh y cheloveka. Laboratornye zhyvotnye dlia nauchnykh issledovanyi. Nauchno-praktycheskyi zhurnal, 3, 33-48. doi: 10.29296/2618723X-2018-03-04 (in Russian).

Kondrakhyn, Y. P., Arkhypov, A. V., Levchenko, V. Y., Talanov, H. A., Frolova L. A., Novykov V.E. (2004) Metody veterynarnoi klinicheskoi laboratornoi diahnostiki.[Methods of veterinary clinical laboratory diagnostics]. M.: Kolos (in Ukrainian).

Kotsyumbas, H., Dancovych, R., \& Vretsona, N. (2018). Pathomorphology and diagnosis of dogs poisoning with isoniazid. Scientific Messenger of LNU of Veterinary Medicine and Biotechnologies. Series: Veterinary Sciences, 20(83), 108-114. doi: $10.15421 /$ nvlvet8321.

Kovalchuk, O., \& Horalska, I. (2018). The features of the course and some diagnostic aspects of pancreatitis in cats. Scientific Messenger of LNU of Veterinary Medicine and Biotechnologies. Series: Veterinary Sciences, 20(88), 94-97. doi: 10.32718/nvlvet8817.

Kravchenko, S. O., \& Bobrova, V. V. (2018). Ultrasonohrafichni zminy za hostrykh ta khronichnykh zapalen pidshlunkovoi zalozy u sviiskykh kotiv. Visnyk Poltavskoi derzhavnoi ahrarnoi akademii, 1, 138-142. URL: http://nbuv.gov.ua/UJRN/VPDAA 2018 129 (in Ukrainian).

Ksenulis, P., \& Shtainer, Y. (2009) Pankreatyt u koshek [Pancreatitis in cats] Fokus, 2, 11-20 (in Ukrainian).

Kuksenko, Y. V. (2002). Pankreatyt. Problemy veterynarnoho obsluhovuvannia dribnykh domashnikh tvaryn [Pancreatitis. Problems of veterinary care for small pets.] Zbirnyk materialiv VII mizhnarodnoinaukovoi-praktychnoi konferentsii, Kyiv, 41-43 (in Ukrainian).

Levchenko, V. I., Vlizlo, V. V., Kondrakhin, I. P., Melnychuk, D. O., Apukhovska, L. I., Halias, V. L., Holovakha, V. I., Sakhniuk, V. V., Tomchuk, V. A., Hryshchenko, V. A., \& Tsvilikhovskyi, M. I. (2002). Veterynarna klinichna biokhimiia. [Veterinary Clinical Biochemistry]. Bila Tserkva (in Ukrainian).

Meier, D., \& Kharvy, Dzh. (2007). Veterynarnaia laboratornaia medytsyna. Interpretatsija i diahnostika [Veterinary laboratory medicine. Interpretation and diagnosis]. M.: Sofyon (in Ukrainian).
Milastnaia, A., \& Dukhnitsky, V. (2019). Clinical and pathogenetic changes in dogs with chronic pancreatitis. Scientific Messenger of LNU of Veterinary Medicine and Biotechnologies. Series: Veterinary Sciences, 21(94), 174-178. doi: 10.32718/nvlvet9432.

Morar, Y. K., Yvashchuk, A. Y., Davydenko, Y. S., Riaboi, S. Y., \& Vytkovskaia, S. V. (2012). Vliyanie vnutribriushnoi hipertenzii na patomorfolohicheskie osobennosti techeniya ostroho destruktivnoho pankreatyta $\mathrm{v}$ eksperimente [Effect of intraperitoneal hypertension on the pathomorphological features of the course of acute destructive pancreatitis in the experiment] Patolohyia, 2(25), 95-97 (in Russian).

Tuboltseva, N. V., \& Zhukov, V. M. (2018) Orhanopatolohyia podzheludochnoi zhelezы koshek [Organopathology of the pancreas of cats.] Vestnik Altaiskoho hosudarstvennoho ahrarnoho universiteta, 9(167), 25-31 (in Russian).

Tymoshenko, O. P. (2007). Informatyvnist sonohrafichnoho doslidzhennia $u$ diahnostytsi zakhvoriuvan pidshlunkovoi zalozy sobak.[ Informative value of sonographic research in the diagnosis of pancreatic diseases in dogs] Visnyk Bilotserkivskoho derzhavnoho ahrarnoho universytetu, 44, 101-103 (in Ukrainian).

Yablonska, O. V. (2007). Vykorystannia laboratornykh tvaryn u eksperymentakh.[ Use of laboratory animals in experiments.] Metodychni vkazivky, K.: Vyd. tsentr NAU, 3-16 (in Ukrainian).

Zinenko, D. Yu., \& Berehovenko, I. M. (2008). Mikrotsyrkuliatorni y patomorfolohichni zminy $u$ rozvytku eksperymentalnoho hostroho pankreatytu u shchuriv. Morfolohiia, 1, 33-40 (in Ukrainian).

Zinenko, D. Yu., \& Tverdokhlib, I. V. (2017). Ultrastruktrni zminy hemomikrotsyrkuliatsii ta parenkhimy pidshlunkovoi zalozy pry rozvytku eksperymentalnoho hostroho pankreatytu u shchuriv. Svit medytsyny ta biolohii, 3(61), 114-115. doi: 10.26724/2079-83342017-3-61-114-119 (in Ukrainian).

Zinenko, D. Yu., \& Tverdokhlib, I. V. (2020). Ultrastrukturna kharakterystyka hemomikrotsyrkuliatornoho rusla ta parenkhimatoznostromalnykh elementiv pidshlunkovoi zalozy ta pechinky $\mathrm{V}$ modeli hostroho pankreatytu $\mathrm{Z}$ vykorystanniam riznykh doz taurokholatu natriiu. Morfolohiia, 14(1), 23-26. doi: 10.26641/19979665.2020.1.23-34 (in Ukrainian). 